\title{
EFFECT OF PROTEIN ENRICHED MINERAL SALT ON BEEF PRODUCTION IN Hemarthria altíssima PASTURES
}

\author{
KAPP, O. ${ }^{1}$; STRACK, A.G. ${ }^{1}$; MOLETTA, J.L. ${ }^{2}$; PEROTTO, D. ${ }^{2}$; BREN, L. ${ }^{3}$ \\ ${ }^{1}$ Graduandos - UEPG. Bolsistas PIBIC/CNPQ/IAPAR; \\ ${ }^{2}$ Pesquisador - Instituto Agronômico do Paraná; \\ ${ }^{3}$ Mestrando - Curso de Pós Graduação em Ciências Veterinárias - UFPR.
}

This project has been carried out with the objective of evaluating the effect of protein supplementation on the performance of beef steers maintained in Hemarthia pastures during winter (May 5th through August 31st ,2000) at Estação Experimental Fazenda Modelo, IAPAR, Ponta Grossa - PR. Thirty six Canchim steers, with initial average age of 10 months and initial average weight of $190 \mathrm{~kg}$ were randomly alloted to the following treatments: Control - mineral salt only, commercial protein containing mineral salt, and on farm prepared protein containing mineral salt. The average intake (grams/animal/day) was 460, 250 and 70, respectively, for Commercial, on Farm and Control treatments. Animals were weighed at 28 day intervals after a period of $14 \mathrm{~h}$ without food. Average total gain (kg/animal) was superior $(20,25 \mathrm{~kg}),(P<0,01)$ for animals that received the on farm made mineral salt - protein misture. Animals that received the Commercial mineral salt - protein mixture last $2,08 \mathrm{~kg}$ during the control mineral salt last $13,67 \mathrm{~kg}(P<0,01)$.

Key Words: Performance, Hemártrhia altíssima ex. Flórida, protein - mineral mix. 